\title{
Effects of ocean warming on larval development of Patella ordinaria from the Canary Islands
}

\author{
Adriana Rodríguez ${ }^{\mathrm{a}, \mathrm{b}, *}$, Martí Vilanova $^{\mathrm{a}}$, Alberto Brito $^{\mathrm{a}}$ \\ ${ }^{a}$ Grupo de Investigación BIOECOMAC, Dpto.Biología Animal, Edafología y Geología.UD Ciencias Marinas, Universidad de La Laguna. 38071, \\ Tenerife, Canary Islands, Spain \\ ${ }^{\mathrm{b}}$ Biodiversity and Conservation Research Group, IU-ECOAQUA, Universidad de Las Palmas de Gran Canaria, Marine Scientific and Technological \\ Park, Crta. a Taliarte s/n, 35214, Telde, Gran Canaria, Canary Islands, Spain
}

\section{A R T I C L E I N F O}

\section{Article history:}

Received 31 January 2020

Received in revised form 6 August 2020

Accepted 7 September 2020

Available online 8 September 2020

\section{Keywords:}

Ocean warming

Larval development

Patella ordinaria

Survival

Early stages

\begin{abstract}
A B S T R A C T
Ocean warming is causing Sea Surface Temperature (SST) to rise, which is projected to reach +2 to $+4.5{ }^{\circ} \mathrm{C}$ by the end of the 21st century. Temperature is considered the most important factor controlling the distribution, physiology, morphology and behavior of marine invertebrates. Early life history stages appear to be particularly sensitive to ocean warming. Effects of ocean warming on larval development have been documented in a wide range of invertebrate species; however, few studies have tested the effects of temperature on gastropod larvae. Here, we assessed the effects of two seawater temperature treatments: control $\left(20^{\circ} \mathrm{C}\right)$ and high $\left(25^{\circ} \mathrm{C}\right)$, on survival and larval development of Patella ordinaria through manipulative experiments. Data were analyzed using two-way ANOVA by permutations. To evaluate the effects of temperature and time on larval development, at each larval stage (oocyte, 2 cells, 4 cells, morula, trochophore, veliger, pediveliger), two-way permutational multivariate analysis of variance (PERMANOVA) was performed. In both analyses, temperature $\left(20^{\circ} \mathrm{C}\right.$ vs. $\left.25^{\circ} \mathrm{C}\right)$ and time $(3,6,19,24,28,32$ and $42 \mathrm{~h})$ were used as fixed factors. The results showed a negative impact of high temperature on larval development and survival of $P$. ordinaria, and the implications are discussed. The early developmental stages of $P$. ordinaria larvae are studied for the first time.
\end{abstract}

(C) 2020 Elsevier B.V. All rights reserved.

\section{Introduction}

As a consequence of increased greenhouse gases concentration, sea surface temperatures (SST) have risen considerably (Bindoff et al., 2007). Ocean warming is causing a SST rise projected to reach +2 to $+4.5{ }^{\circ} \mathrm{C}$ by the end of the 21 st century (IPCC, 2014). Temperature is considered the most important factor controlling the distribution, physiology, morphology and behavior of marine invertebrates (Doney et al., 2009). Diverse species can broaden their distribution range, leading towards a global tropicalization (Perry et al., 2005; Horta e Costa et al., 2013) and meridionalization (Brito et al., 2005; Yapici et al., 2016) of marine biota. Responses to climate change stressors seem to be highly species-specific and effects on fitness-related parameters can be either negative or positive (Wittmann and Pörtner, 2013). However, the habitats the species occupy seem

\footnotetext{
* Corresponding author at: Biodiversity and Conservation Research Group, IU-ECOAQUA, Universidad de Las Palmas de Gran Canaria, Marine Scientific and Technological Park, Crta. a Taliarte s/n, 35214, Telde, Gran Canaria, Canary Islands, Spain.

E-mail address: adrianar@ull.edu.es (A. Rodríguez).
}

to play an important role. Species with temperate affinities can show the negative effects of increased temperature, such as on the survival of those already at their distribution limit (Harley et al., 2006). In contrast, species with tropical affinities can show positive responses to temperature increase as their distribution range broadens (López et al., 2020).

Early life history stages are considered to be more sensitive to environmental stress than adult stages and such impacts have received much attention (reviewed by Dupont et al., 2009; Byrne and Przeslawski, 2013). These life stages may be particularly sensitive to ocean warming (Pechenik, 1987; Gosselin and Qian, 1997). In fact, the effects of ocean warming on larval development have been documented in a wide range of invertebrate species (O'Connor et al., 2007; see review by Dupont et al., 2009). Survival, development and growth of early life stages may have particularly severe consequences for species where their persistence or recovery from disturbance hinges on larval recruitment (Byrne et al., 2011; Byrne and Przeslawski, 2013). However, few studies have tested the effects of temperature on gastropod larvae, although some have assessed the impacts of temperature and $\mathrm{pH}$ changes on Patella vulgata (Findlay et al., 2009), the opisthobranch Stylocheilus striatus (Allen, 2012) and temperature, 
salinity and/or ocean acidification on Nassarius genus (Zhao and Jin, 2001; Zhao et al., 2009; Zhang et al., 2014).

The Canary Islands are an archipelago in a subtropical region where the gastropod Patella crenata (Class Gastropoda, Family Patellidae), recently denominated Patella ordinaria (Titselaar, 2019) is distributed. Its populations have undergone severe decline in recent decades as a consequence of intensive anthropogenic pressure (Batista, 2001; Cabrera, 2001; Navarro et al., 2015; González-Lorenzo, 2015). This species lives in intertidal and subtidal habitats on all islands in the archipelago (Batista, 2001; González-Lorenzo, 2015). Some studies have described the ecology and biology of $P$. ordinaria (see Batista, 2001; Cabrera, 2001; Navarro et al., 2015; González-Lorenzo, 2015); however, how ocean warming affects it has not yet been investigated.

The Canary Islands are near to the Saharan upwelling. The cold Canary Current and trade winds give rise to a variety of mesoscale phenomena (Barton et al., 1998, 2004). These phenomena generate a longitudinal Sea Surface Temperature difference that can exceed $2{ }^{\circ} \mathrm{C}$ between the islands of Lanzarote (East) and El Hierro (West) (Barton et al., 1998). In addition, recent studies show a rising trend of $0.28{ }^{\circ} \mathrm{C}$ per decade between $1982-2013$ in the Canary Islands (Vélez-Belchí et al., 2015).

This study is focused on the effects of temperature on survival and larval development in $P$. ordinaria. Since it is a species with temperate affinities, we hypothesized that it would show its vulnerability to ocean warming in future climate change scenarios in the form of lower survival rates of its larval stages.

\section{Materials and methods}

We ran a manipulative experiment in the laboratory to assess the effects of temperature rise, according to the ocean warming predictions on Patella ordinaria larval development.

\subsection{Limpet collection}

Twelve mature specimens were collected by snorkel divers in February 2019, coinciding with availability of reproductively mature individuals (see González-Lorenzo, 2015) in a natural habitat located in the municipality of Candelaria $\left(28^{\circ} 22^{\prime} 6.939^{\prime \prime}\right.$ $\mathrm{N}, 16^{\circ} 21^{\prime} 41.982$ " 0 ). This locality is constituted of artificial blocks where these animals are settled. The individuals were transported to the laboratory under controlled humidity and darkness immediately after collection, where they were placed in an aquarium at $20{ }^{\circ} \mathrm{C}$ with filtered seawater (FSW).

\subsection{Spawning induction and fertilization}

As limpets do not show external sexual dimorphism, all individuals were exposed to spawning induction by different techniques reported in the bibliography, along with newly tested approaches. The chosen techniques consisted of strong continuous air bubbling and/or injecting $\mathrm{KCl}$, a compound used in other invertebrates to induce spawning (Corpuz, 1981; Ferranti et al., 2018; Kay and Emlet, 2002).

For the bubbling method, seven individuals were deposited in seven $100 \mathrm{ml}$ sterile beakers in FSW. Seawater was vigorously bubbled for $2 \mathrm{~h}$ using standard Eheim aquarium oxygenators positioned at the bottom of each beaker (Kay and Emlet, 2002; Ferranti et al., 2018). The $\mathrm{KCl}$ technique was applied to seven individuals by injecting $1.5 \mathrm{ml}$ of $\mathrm{KCl}(0.1 \mathrm{M})$ through the mantle. Finally, after bubble treatment seven females spawned successfully and three males released sperm from the $\mathrm{KCl}$ technique. Eggs were collected in the FSW, while male gametes were collected directly from each individual using a micropipette and kept at
$4{ }^{\circ} \mathrm{C}$ until used. Gametes were mixed before contact with those of the opposite sex.

To carry out fertilization assays, eggs and sperm were added together in beakers with $100 \mathrm{ml}$ of filtered seawater (FSW) for one hour at $20{ }^{\circ} \mathrm{C}$, in a proportion of 6000 eggs to 6 sperm drops. Afterwards, the solution was filtered $(60 \mu \mathrm{m})$ and treated at different temperatures. Before fecundation, sperm mobility and eggs state were checked. No eggs were exposed to alkalinization conditions, despite such recommendations in the literature (Ferranti et al., 2018).

\subsection{Experimental setup}

Temperature was manipulated in two 401 aquariums, one was a control treatment $\left(20^{\circ} \mathrm{C}\right)$ corresponding to natural sea water conditions in the Canary Islands in winter and another high temperature $\left(+5{ }^{\circ} \mathrm{C}\right)$, predicted for the year 2100 in the region, (IPCC 2013). These were warmed and kept at constant temperatures by Eheim Jager heaters. Three replicates (3 independent beakers) were placed on a support in each aquarium, consisting of $100 \mathrm{ml}$ of autoclaved filtered seawater with an average density of 14 fertilized eggs/ml. All replicates were subjected to a $14 / 10 \mathrm{~h}$ light/dark cycle, with constantly aerated seawater in each beaker (Fig. 1).

Larval survival (measured as number of live larvae) and embryonic stage were assessed in the samples after $48 \mathrm{~h}$. Counts were done by taking 3 aliquots of $1 \mathrm{ml}$ from each replicate beaker and observing under the microscope. The sampling times were $3,6,19,24,28,32$ and 42. In each aliquot, the number of eggs was registered at the different stages of cell division: oocyte with chorion, fertilized egg, 2 cells, 4 cells, morula, trochophore, veliger and pediveliger larvae under the microscope at each sampling time. For all combinations of temperature and time, 3 replicates were performed where $3 \mathrm{ml}$ of each replicate were counted.

\subsection{Data analysis}

In order to assess the effects of seawater temperature on larval survival in the species, the data were analyzed by means of a twoway PERMANOVA, where temperature (2 levels; $20^{\circ} \mathrm{C}$ vs. $25^{\circ} \mathrm{C}$ ) and time (7 levels; 3 h, 6 h, 19 h, 24 h, 28 h, 32 h and 42 h) were used as fixed factors.

To evaluate the effects of temperature and time on embryonic development, a permutational multivariate analysis of variance (PERMANOVA) was performed with the same design as described above.

Euclidean distances were used for all analyses of variance, and the respective significant terms were examined a posteriori with pairwise comparisons by permutations (Anderson, 2005). If there were insufficient possible permutations for a reasonable test, corrected p-values were obtained with Monte Carlo random draws from the asymptotic permutation distribution. All statistical analyses were carried out using PRIMER6 \& PERMANOVA+ v.1.0.1 software.

\section{Results}

\subsection{Larval development}

At the end of the experiment, larval development of $P$. ordinaria was described for the first time in control treatment. Complete larval development took at least $42 \mathrm{~h}$, passing through eight different stages: oocyte with chorion (Fig. 2A), fertilized egg were observed at $1 \mathrm{~h}$ after fertilization (Fig. 2B). Early divisions were fast, two blastomere embryos at $3 \mathrm{~h}$ (Fig. 2C), four blastomere embryos and morula stages were observed within 3-6 h 


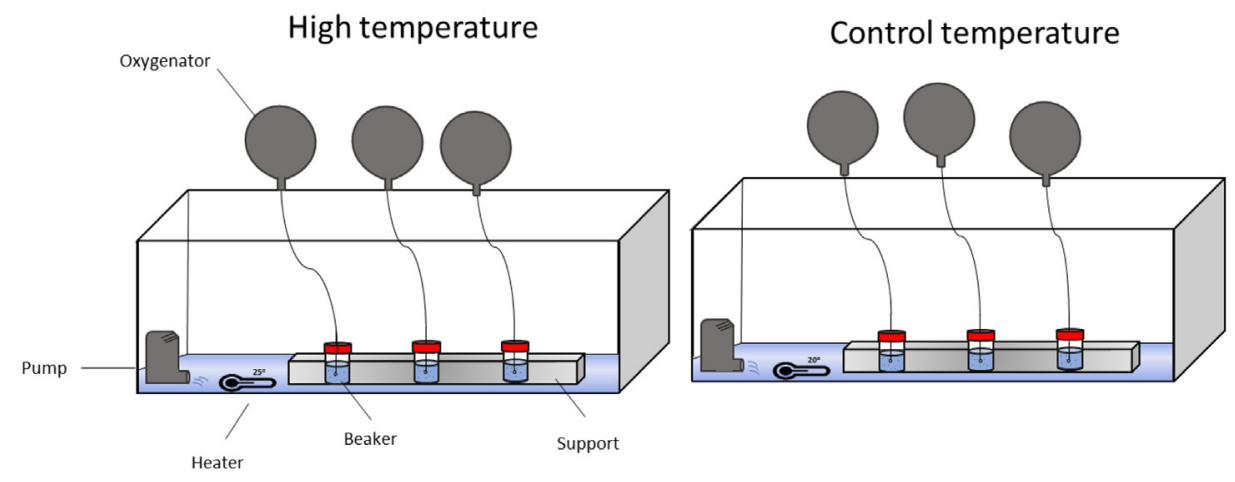

Fig. 1. Detail of experimental setup.

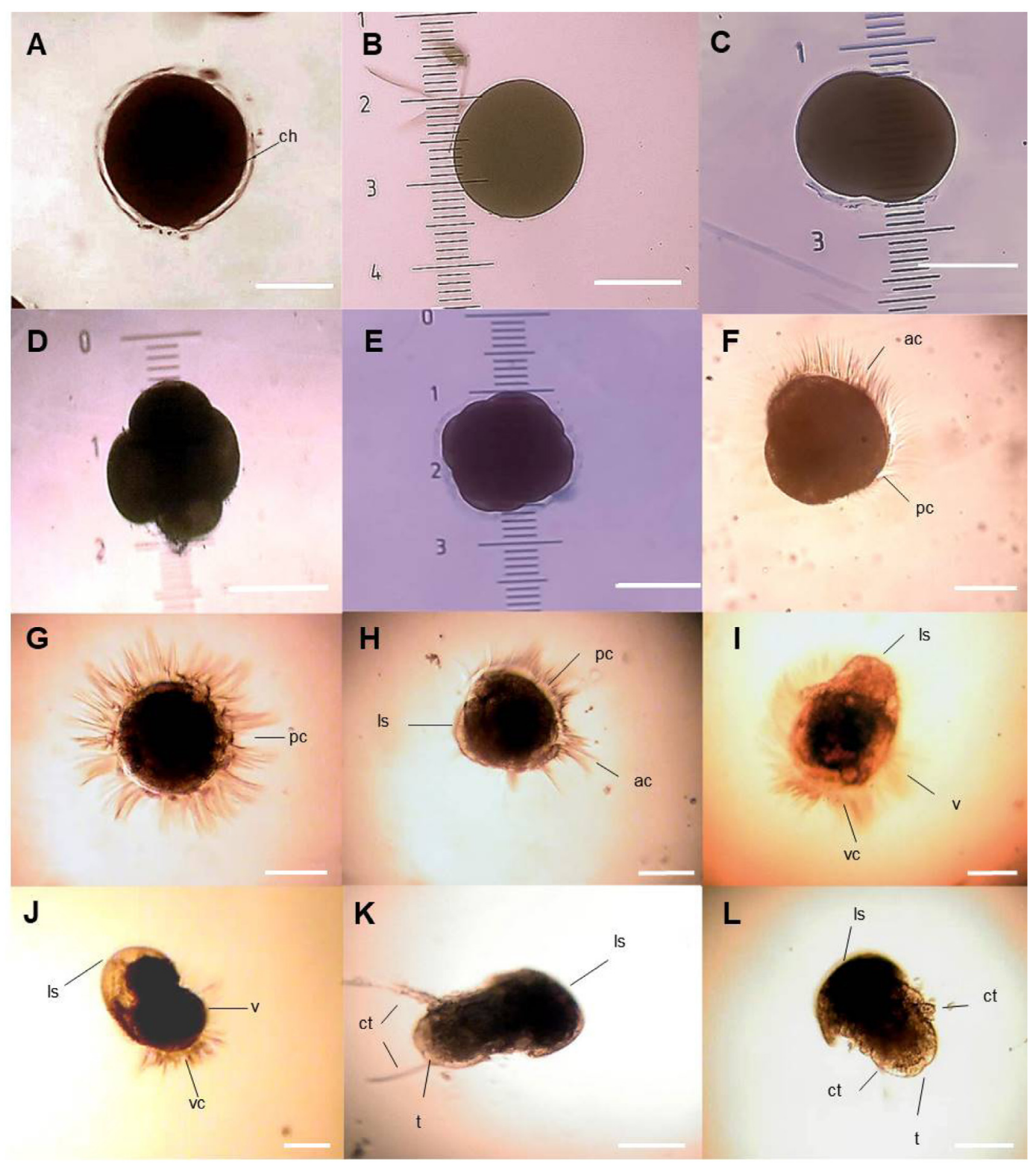

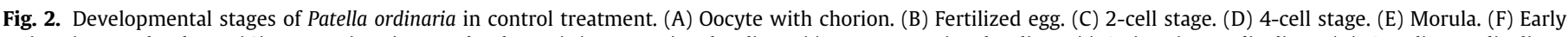

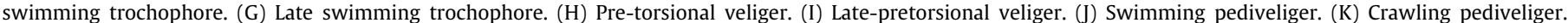

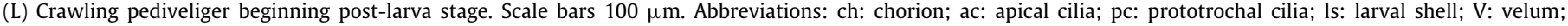
vc: velar cilio; ct: cephalic tentacle; t: telotroch. 
Table 1

(A) Result of the two-way PERMANOVA comparing survival larvae of Patella ordinaria in two temperature treatments $\left(\operatorname{Tr}=20^{\circ} \mathrm{C}\right.$ vs. $\left.\operatorname{Tr}=25^{\circ} \mathrm{C}\right)$ and between sampled times (Ti=3 h vs. 6 h vs. 19 h vs. 24 h vs. 28 h vs. 32 h vs. 42 h). (B) A posteriori pairwise comparisons of the significant interaction of factor 'Temperature treatment $x$ Time'. Significant results $(p<0.05)$ are shown in bold. (A) Survival

\begin{tabular}{llllll}
\hline Factor & DF & SS & MS & Pseudo-F & P (perm) \\
\hline Tr & 1 & $5.1852 e^{-3}$ & $5.1852 e^{-3}$ & $1.5051 e^{-3}$ & 0.9684 \\
Ti & 6 & 341.92 & 56.986 & 16.541 & $\mathbf{0 . 0 0 0 1}$ \\
TrxTi & 6 & 48.976 & 8.1627 & 2.3693 & $\mathbf{0 . 0 4 9 6}$ \\
Res & 28 & 96.465 & 3.4452 & & \\
Total & 41 & 487.36 & & & \\
\hline (B) Pair wise & & & & & \\
\hline Treatment & Time & t & P(perm) & Permutations & P(MC) \\
& & & & number & \\
\hline $20{ }^{\circ} \mathrm{C}$ vs. $25{ }^{\circ} \mathrm{C}$ & $3 \mathrm{~h}$ & 2.1767 & 0.0995 & 10 & 0.0905 \\
$20{ }^{\circ} \mathrm{C}$ vs. $25^{\circ} \mathrm{C}$ & $6 \mathrm{~h}$ & 0.2835 & 1 & 6 & 0.798 \\
$20{ }^{\circ} \mathrm{C}$ vs. $25{ }^{\circ} \mathrm{C}$ & $19 \mathrm{~h}$ & 1.225 & 0.3037 & 10 & 0.2895 \\
$20{ }^{\circ} \mathrm{C}$ vs. $25{ }^{\circ} \mathrm{C}$ & $24 \mathrm{~h}$ & 1.0335 & 0.4994 & 10 & 0.364 \\
$20{ }^{\circ} \mathrm{C}$ vs. $25^{\circ} \mathrm{C}$ & $28 \mathrm{~h}$ & 1.4033 & 0.1993 & 6 & 0.2404 \\
$20{ }^{\circ} \mathrm{C}$ vs. $25{ }^{\circ} \mathrm{C}$ & $32 \mathrm{~h}$ & 1.2562 & 0.2024 & 5 & 0.281 \\
$20{ }^{\circ} \mathrm{C}$ vs. $25{ }^{\circ} \mathrm{C}$ & $42 \mathrm{~h}$ & 3.4684 & 0.1003 & 4 & $\mathbf{0 . 0 2 8 2}$ \\
\hline
\end{tabular}

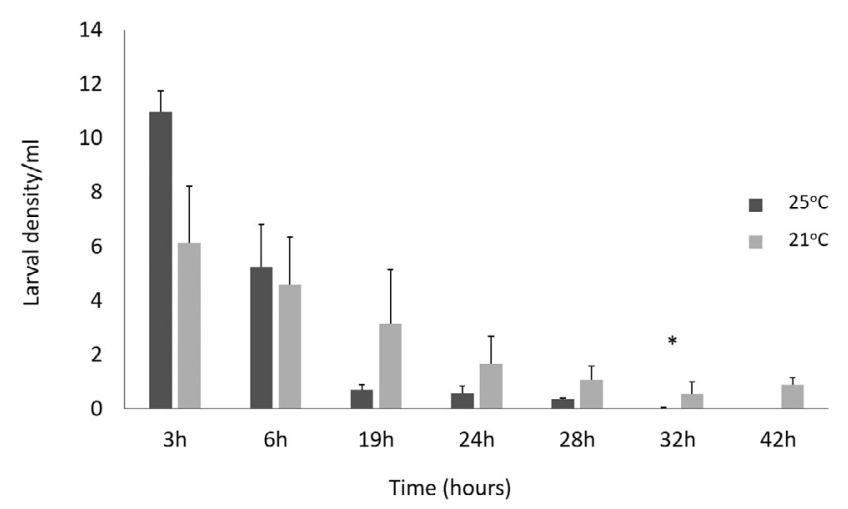

Fig. 3. Mean values \pm SE of density in larvae $/ \mathrm{ml}$ of Patella ordinaria at each time sampled ( 3 h; 6 h; 19 h; 24 h; 28 h; 32 h; 42 h). Significant differences are shown with an asterisk $\left(^{*}\right)$.

(Fig. 2 D-E).Early trochophores were observed between 6-19 h (Fig. 2 F-G).Early veliger and veliger were registered between $32-$ $42 \mathrm{~h}$ post fertilization (Fig. $2 \mathrm{H}-\mathrm{I}$ )and swimming and crawling pediveliger stages were observed at $42 \mathrm{~h}$ (Fig. $2 \mathrm{~J}-\mathrm{L}$ ).

\subsection{Larval survival}

Survival decreased with time, with significant differences in treatment*time (Table $1 \mathrm{~A}$ ). A posteriori pairwise tests revealed that these differences appeared among temperature treatments at $42 \mathrm{~h}$ (Table $1 \mathrm{~B})$.

At $42 \mathrm{~h}$ post-fertilization, in control treatment $\left(20^{\circ} \mathrm{C}\right)$ larval density was 0.88 larvae $/ \mathrm{ml}$, while at $\left(25^{\circ} \mathrm{C}\right)$ treatment no larvae were observed ( 0 larvae $/ \mathrm{ml}$ ). The highest densities were observed at the beginning of the experiment in both treatments, with higher densities at $25^{\circ} \mathrm{C}$ than at $20{ }^{\circ} \mathrm{C}$ (see Fig. 3).

\subsection{Larval development}

Significant differences in larval development were observed between temperature treatments and times (Table 2A), where in the control treatment all larval stages were observed. These differences were observed between temperature treatments at $42 \mathrm{~h}$ (Table 2B).
Table 2

(A) Results of the two-way PERMANOVA comparing the effect of temperature (Tr) and time (Ti) on embryonic development of Patella ordinaria (B) A posteriori pairwise comparisons of the significant interaction of factors 'Temperature treatment $\times$ Time'. Significant differences are shown in bold.

\begin{tabular}{llllll}
\hline \multicolumn{2}{l}{ (A) Larval development } & & & & \\
\hline Factor & DF & SS & MS & Pseudo-F & P (perm) \\
\hline $\mathrm{Tr}$ & 1 & 25.813 & 25.813 & 4.6295 & $\mathbf{0 . 0 0 5 3}$ \\
$\mathrm{Ti}$ & 6 & 225.45 & 37.575 & 6.7389 & $\mathbf{0 . 0 0 0 1}$ \\
$\mathrm{TrxTi}$ & 6 & 118.1 & 19.684 & 3.5301 & $\mathbf{0 . 0 0 0 1}$ \\
Res & 28 & 156.13 & 5.5759 & & \\
Total & 41 & 525.49 & & & \\
\hline (B) Pairwise tests & & & & & \\
\hline Treatment & Time & $\mathrm{t}$ & $\mathrm{P}$ (perm) & Permutations & $\mathrm{P}(\mathrm{MC})$ \\
& & & & number & \\
\hline $20{ }^{\circ} \mathrm{C}$ vs. $25{ }^{\circ} \mathrm{C}$ & $3 \mathrm{~h}$ & 1.6969 & 0.2124 & 10 & 0.1323 \\
$20{ }^{\circ} \mathrm{C}$ vs. $25{ }^{\circ} \mathrm{C}$ & $6 \mathrm{~h}$ & 0.91185 & 0.6982 & 10 & 0.4678 \\
$20{ }^{\circ} \mathrm{C}$ vs. $25{ }^{\circ} \mathrm{C}$ & $19 \mathrm{~h}$ & 1.3252 & 0.2002 & 10 & 0.2301 \\
$20{ }^{\circ} \mathrm{C}$ vs. $25{ }^{\circ} \mathrm{C}$ & $24 \mathrm{~h}$ & 1.1849 & 0.2046 & 10 & 0.2931 \\
$20{ }^{\circ} \mathrm{C}$ vs. $25{ }^{\circ} \mathrm{C}$ & $28 \mathrm{~h}$ & 0.99172 & 0.5922 & 10 & 0.4214 \\
$20{ }^{\circ} \mathrm{C}$ vs. $25{ }^{\circ} \mathrm{C}$ & $32 \mathrm{~h}$ & 1.4707 & 0.2069 & 10 & 0.1858 \\
$20{ }^{\circ} \mathrm{C}$ vs. $25{ }^{\circ} \mathrm{C}$ & $42 \mathrm{~h}$ & 2.7931 & 0.1046 & 10 & $\mathbf{0 . 0 3 2 4}$ \\
\hline
\end{tabular}

The first stages (oocytes and oocytes with chorion) were abundant in the two temperature treatments throughout the entire process. The presence of oocytes without a membrane was greater in the control treatment than in the temperature treatment (16 oocytes/ml and 9 oocytes/ml respectively), while the proportion of oocytes with a membrane varied around 5 oocytes $/ \mathrm{ml}$ in the two treatments, developing slightly faster in the temperature treatment (see Fig. 4).

The 2cell, 4cell and morula stages began to be present at $3 \mathrm{~h}$ and $6 \mathrm{~h}$ in both treatments. The trochophores were observed in the control samples after $7 \mathrm{~h}$, while at elevated temperature trochophores were observed only at $32 \mathrm{~h}$. The veliger state was only observed in the control treatment after $32 \mathrm{~h}$ (Fig. 4).

The highest trochophore percentages were observed in the control treatment at 19, 24 and 28 h (Fig. 4A) while at elevated temperature the percentage was very low, with densities of 0.02 larvae/ml (Fig. 4B). Finally, the veliger and pediveliger were only present in the control treatment at 32 and $42 \mathrm{~h}$ respectively and with values around 1 larva /ml (Fig. 4).

\section{Discussion}

This study describes for the first time the larval cycle of Patella ordinaria. It also shows the negative effects of temperature increase on its larval development in laboratory experiments.

The early stages of larval development in Patella ordinaria appear in this study to be very similar to other related limpet species such as P. ferruginea (Espinosa et al., 2010; Guallart et al., 2020) or P. vulgata (Dodd, 1957; Wanninger et al., 1999) and slightly faster than those recorded in $P$. caerulea (Wanninger et al., 1999). In both cases, development times did not exceed $48 \mathrm{~h}$, making these species very vulnerable to any environmental alteration to which they are subjected (Morgan, 1995; Guallart and Templado, 2012; Parker et al., 2009).

As in various other marine organisms, the larval development of $P$. ordinaria was negatively affected by the projected future temperature rise. Similar results have been observed in other invertebrates such as the echinoderm species Heliocidaris erythrogramma (Byrne et al., 2009), where an increase of $6{ }^{\circ} \mathrm{C}$ led to an anomalous and incomplete larval development, or in Meridiastra calcar where a $2{ }^{\circ} \mathrm{C}$ rise decreased larval size and survival (Nguyen et al., 2012). However, positive responses have been observed in other early stages of cnidarian species (Chua et al., 2013). 


\section{A}

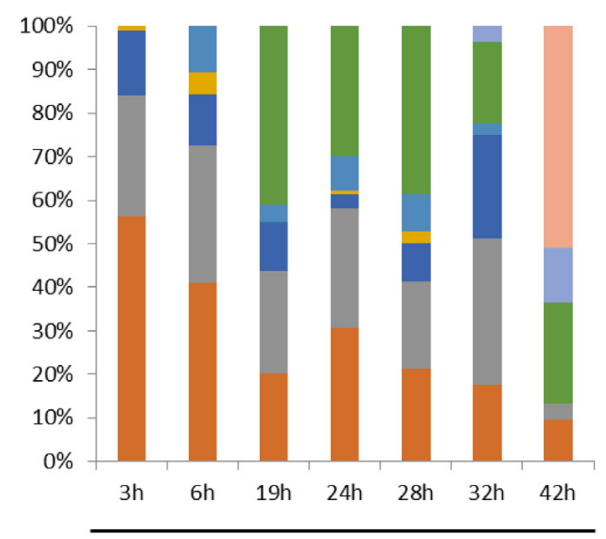

time

\section{B}

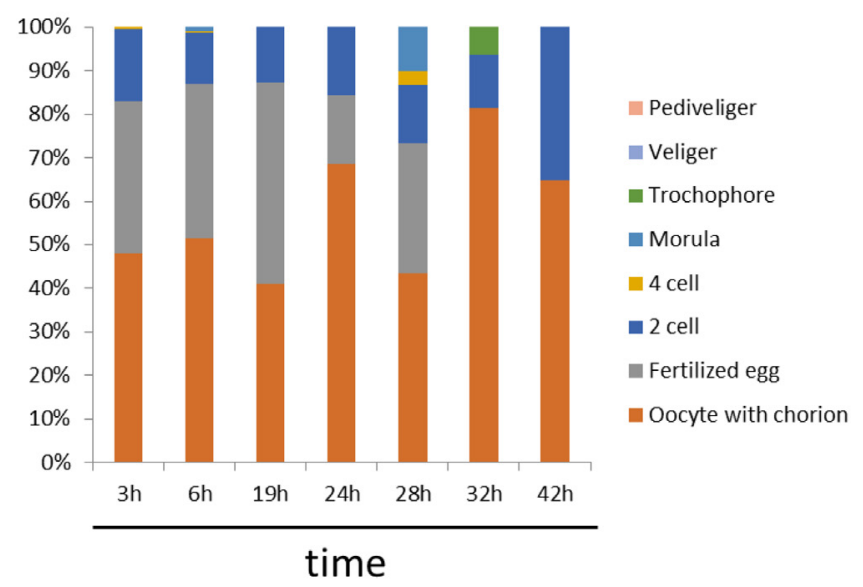

Fig. 4. Cumulative percentage of early larval stages for each time sampled. A. Under control temperature treatment. B. Under high temperature treatment.

This study shows how the temperature rise expected at the end of the century is likely to negatively affect larval development in $P$. ordinaria, at least under laboratory conditions. This increase $\left(5^{\circ} \mathrm{C}\right)$ prevented the larval cycle of our target species from being fully accomplished. During the first stages, the higher temperature at first accelerated larval development but soon later halted it.

Since not all marine organisms respond equally to these situations, $P$. ordinaria is a gastropod linked to cold-temperate waters, so one would not expect a temperature increase to favor its larval development. Even so, there are species that have benefited from the progressive SST increase, as part of ongoing tropicalization or meridionalization processes. A case in point is the sea urchin Diadema africanum, favoring its larval development (Hernández et al., 2010).

Other work carried out with some species of the genera Mytilus (Gaylord et al., 2011; Gazeau et al., 2010), Crassostrea (Miller et al., 2009) and Stylocheilus (Allen, 2012) has revealed the vulnerability of these types of mollusks to alterations in $\mathrm{pH}$, also derived from climate change. This further issue would have been interesting to include in this experiment, since an interaction between temperature and $\mathrm{pH}$ could modify the response to the temperature rise, either intensifying or counteracting its effect. Currently there are few studies on the impact of climate change on gastropods and more specifically on the Patella genus.
The present study constitutes a first approach to how climate change affects this important species in the Canary Islands. However, future research using intermediate temperatures, such as $23{ }^{\circ} \mathrm{C}$, is necessary to assess the short term effects of climate change on $P$. ordinaria populations. Indeed, several studies show that some intertidal invertebrates are already living near their physiological tolerance limits (Tomanek, 2008; Somero, 2010). Consequently, already shifting base-line environmental conditions may be pushed to suboptimal or lethal levels by extremes such as heat waves. With these results, this study highlights the need to protect this key species inhabiting rocky bottoms in the Canary Islands in areas considered climatic refuges. These areas have colder temperatures due to their orographic or regional microclimate conditions, naturally affording it more protection, particularly in such areas where warming is not expected to be so pronounced. In this way, survival of $P$. ordinaria populations could at least be ensured on some stretches of the north-eastern coasts of the Canaries. For these and other reasons, there is a continued need to carry out research on how such species will adapt to a future faced with climatic changes, including its impact on newly settled specimens.

\section{CRediT authorship contribution statement}

Adriana Rodríguez: Conceived the work, Field and experimental work, Statistical analyses, Writing of manuscript. Martí Vilanova: Statistical analyses, Writing of manuscript. Alberto Brito: Conceived the work, Field and experimental work.

\section{Declaration of competing interest}

The authors declare that they have no known competing financial interests or personal relationships that could have appeared to influence the work reported in this paper.

\section{Acknowledgments}

This study has benefited from the development of the MIMAR MAC/4.6.d/066 project (INTERREG MAC 2014-2020). AR was cofunded by Universidad de Las Palmas de Gran Canaria, Spain through postdoctoral grant. We acknowledge two anonymous reviewers who improved the paper.

\section{References}

Allen, T.R., 2012. The effects of ocean acidification and sea surface warming on the embryonic development of the opisthobranch gastropod Stylocheilus striatus. UC Berkeley: UCB Moorea Class: Biology and Geomorphology of Tropical Islands. Retrieved from https://escholarship.org/uc/item/3977m4tq.

Anderson, M.J., 2005. Permanova: A Fortran Computer Program for Permutational Multivariate Analysis of Variance. Department of Statistics, University of Auckland, Auckland.

Barton, E.D., Arístegui, J., Tett, P., Canton, M., García-Braun, J., Hernández, L., Nykhaer, L., Almeida, C., Alumunia, J., Ballesteros, S., Basterretxea, G., Escánez, J., García-Weill, L., Hernández-Guerra, A., Lopez-Laatzen, F., Molina, R., Montero, M.F., Navarro-Pérez, E., Rodríguez, J.M., van Lenning, K., Vélez, H., Wild, K., 1998. The transition zone of the Canary Current upwelling region. Prog. Oceanogr. 41, 455-504. http://dx.doi.org/10.1016/s0079-6611(98) 00023-8.

Barton, E.D., Arístegui, J., Tett, P., Navarro-Pérez, E., 2004. Variability in the Canary Islands area of filament-eddy exchanges. Prog. Oceanogr. 62, 71-94. http://dx.doi.org/10.1016/j.pocean.2004.07.003.

Batista, C., 2001. El marisqueo en la prehistoria de Gran Canaria. Vector plus 18, 67-76.

Bindoff, N.L., Willebrand, J., Artale, V., Cazenave, A., Gregory, J., et al., 2007. Observations: Oceanic climate change and sea level. In: Solomon, S., Oin, D. Manning, M., Chen, Z., Marquis, M., Averyt, K.B., Tignor, M., Miller, H.L. (Eds.), Climate Change 2007: The Physical Science Basis. Contribution of Working Group I To the Fourth Assessment Report of the Intergovernmental Panel on Climate Change. Cambridge University Press, Cambridge, United Kingdom and New York, NY, USA. 
Brito, A., Falcón, J.M., Herrera, R., 2005. Sobre la tropicalización reciente de la ictiofauna litoral de las Islas Canarias y su relación con los cambios ambientales y actividades antrópicas. Vieraea 33, 515-525.

Byrne, M., Gibson, C., Atkinson, R., Gordon, J., Smith, I., Hughes, D., Taylor, E., Francis, I., 2011. Impact of ocean warming and ocean acidification on marine invertebrate life history stages: Vulnerabilities and potential for persistence in a changing ocean. Annu. Rev. 49, 1-42.

Byrne, M., Ho, M., Selvakumaraswamy, P., Nguyen, H.D., Dworjanyn, S.A., Davis, A.R., 2009. Temperature, but not pH, compromises sea urchin fertilization and early development under near-future climate change scenarios. Proc. R. Soc. B Biol. Sci. 276, 1883-1888. http://dx.doi.org/10.1098/rspb.2008. 1935.

Byrne, M., Przeslawski, R., 2013. Multistressor impacts of warming and acidification of the ocean on marine invertebrates' life histories. Integr. Comp. Biol. 53, 582-596. http://dx.doi.org/10.1093/icb/ict049.

Cabrera, J.C., 2001. Poblamiento e impacto aborigen. In: Fernández-Palacios, J.M., Martín, J. (Eds.), Dir. Naturaleza de Las Islas Canarias. pp. 241-245.

Chua, C.M, Leggat, W., Moya, A., Baird, A.H., 2013. Temperature affects the early life history stages of corals more than near future ocean acidification. Mar. Ecol. Prog. Ser. 475, 85-92.

Corpuz, G.C., 1981. Laboratory culture of Cellana exarata (Reeve, 1854) (Gastropoda: Prosobranchia, Patellidae). Aquaculture 24, 219-231. http://dx.doi. org/10.1016/0044-8486(81)90058-2.

Horta e Costa, B., Batista, M.I., Gonçalves, L., Erzini, K., Caselle, J.E., Cabral, H.N., et al., 2013. Fishers' behaviour in response to the implementation of a marine protected area. PLoS One 8 (6), e65057. http://dx.doi.org/10.1371/journal. pone.0065057.

Dodd, J.M., 1957. Artificial fertilization, larval development and metamorphosis in Patella vulgata L. and Patella caerulea L. Publ. Stazione Zool. Napoli 29, $172-186$.

Doney, S.C., Fabry, V.J., Feely, R.A., Kleypas, J.A., 2009. Ocean acidification: The other $\mathrm{CO}_{2}$ problem. Ann. Rev. Mar. Sci. http://dx.doi.org/10.1146/annurev. marine.010908.163834.

Dupont, S., Havenhand, J.N., Thorndyke, M., 2009. Impact of CO2- driven ocean acidification on early life-history - what we know and what we need to know and what we can do. Biogeosci. Disscuss 6, 3109-3131. http://dx.doi. org/10.1088/17551307/6/46/462006.

Espinosa, F., Rivera-Ingraham, G.A., García-Gómez, J.C., 2010. Early stages of development in the endangered limpet Patella ferruginea (Gmelin, 1791) (Gastropoda: Patellidae). Nautilus (Philadelphia) 124, 51-53.

Ferranti, M.P., Monteggia, D., Asnaghi, V., Chiantore, M., 2018. Artificial reproduction protocol, from spawning to metamorphosis, through noninvasive methods in Patella Caerulea (Linnaeus, 1758). Aquacult. Res. 49, http://dx. doi.org/10.1111/are.13802.

Findlay, H.S., Wood, H.L., Kendall, M.A., Spicer, J.I., Twitchett, R.J., 2009. Calcification, a physiological process to be considered in the context of the whole organism. pp. 2267-2284. http://dx.doi.org/10.5194/bgd-6-2267-2009.

Gaylord, B., Hill, T.M., Sanford, E., Lenz, E.A., Jacobs, L.A., Sato, K.N., Russell, A.D., Hettinger, A., 2011. Functional impacts of ocean acidification in an ecologically critical foundation species. J. Exp. Biol. 214 (15), 2586-2594. http: //dx.doi.org/10.1242/jeb.055939.

Gazeau, F., Gattuso, J.P., Dawber, C., Pronker, A.E., Peene, F., Peene, J., Heip, C.H.R., Middelburg, J.J., 2010. Effect of ocean acidification on early life stages of the blue mussel Mytilus edulis. Biogeosciences 7 (7), 2051-2060. http://dx.doi. org/10.5194/bg-7-2051-2010.

González-Lorenzo, G., 2015. Biología, gestión y conservación de los moluscos (Gastropoda y Bivalvia) con interés marisquero en las Islas Canarias (Thesis). Universidad de La Laguna, p. 175pp.

Gosselin, L, Qian, P., 1997. Juvenile mortality in benthic marine invertebrates. Mar. Ecol. Prog. Ser. 146, 265-282.

Guallart, J., Peña, J., Pérez-Larruscaín, J., Luque, A., Templado, J., 2020. Filling gaps: closing the life cycle of the endareged Meditarranean limpet Patella ferruginea Gmlein, 1791 (Gastropoda, Patellidae). Mediterr. Mar. Sci. 21 (2), 400-419. http://dx.doi.org/10.12681/mms.22508.

Guallart, J., Templado, J., 2012. Patella ferruginea. In: VV.AA. Bases Ecológicas Preliminares Para la Conservación de Las Especies de Interés Comunitario En EspaÑa: Invertebrados. Ministerio de Agricultura, Alimentación y Medio Ambiente, Madrid, 86 pp.

Harley, C.D.G., Hughes, A.R., Hultgren, K.M., Miner, B.G., Sorte, J.B.C., Thornber, C.S., Rodriguez, L.F., Tomanek, L., Williams, S.L., 2006. The impacts of climate change in coastal marine systems. Ecol. Lett. 9, 228-241. http: //dx.doi.org/10.1111/j.1461-0248.2005.00871.x.

Hernández, J.C., Clemente, S., Girard, D., Pérez-Ruzafa, A., Brito, A., 2010. Effect of temperature on settlement and postsettlement survival in a barrensforming sea urchin. Mar. Ecol. Prog. Ser. 413, 69-80. http://dx.doi.org/10. 3354/meps08684.
IPCC, 2014. Climate Change 2014: Impacts, Adaptation, and Vulnerability. Part A: Global and Sectorial Aspects. Contribution of Working Group II To the Fifth Assessment Report of the Intergovernmental Panel on Climate Change. Cambridge University Press, Cambridge, United Kingdom and New York, NY, USA.

Kay, M., Emlet, R., 2002. Laboratory spawning, larval development, and metamorphosis of the limpets Lottia digitalis and Lottia asmi (Patellogastropoda, Lottiidae). Invertebr. Biol. 121, 11-24.

López, C., Moreno, S., Brito, A., Clemente, S., 2020. Distribution of zooxanthellate zoantharians in the Canary Islands: Potential indicators of ocean warming. Estuar. Coast. Shelf Sci. 233, http://dx.doi.org/10.1016/j.ecss.2019.106519.

Miller, A.W., Renolds, A.C., Sobrino, C., Riedel, G.F., 2009. Shellfish face uncertain future in high $\mathrm{CO} 2$ world: Influence of acidification on oyster larvae calcification and growth in estuaries. Plos One 4 (5), http://dx.doi.org/10.1371/ journal.pone.0005661.

Morgan, S.G., 1995. Life and death in the plankton: larval mortality and adaptation. In: McEdward, L. (Ed.), Ecology of Marine Invertebrate Larvae. Vol. 1. CRC Press, Boca Raton.

Navarro, P.G., Ramírez, R., Tuya, F., Fernandez-Gil, C., Sanchez-Jerez, P. Haroun, R.J., 2015. Hierarchical analysis of spatial distribution patterns of patellid limpets in the Canary Islands. J. Moll. Stud. 71, 67-73.

Nguyen, H.D., Doo, S., Soars, N.A., Byrne, M., 2012. Noncalcifying larvae in a changing ocean: warming not acidification/ hypercapnia, is the dominant stressor on development of the sea star meridiastra calcar. Glob Change Biol. 18, 2466-2476. http://dx.doi.org/10.1093/icb/ict049.

O'Connor, M.I.O., Bruno, J.F., Gaines, S.D., Halpern, B.S., Lester, S.E., Kinlan, B.P., Weiss, J.M., 2007. Temperature control of larval dispersal and the implications for marine ecology, evolution, and conservation. http://dx.doi.org/10. 1073/pnas.0603422104.

Parker, L.M., Ross, P.M., O'Connor, W.A., 2009. The effect of ocean acidification and temperature on the fertilization and embryonic development of the Sydney Rock Oyster Saccostrea glomerata (Gould 1850). Glob. Chang. Biol 15 (9), 2123-2136. http://dx.doi.org/10.1111/j.1365-2486.2009.01895.x.

Pechenik, J.A., 1987. Environmental Influences on a Larval Survival and Development. Academic Press, New York, pp. 551-608.

Perry, A., Ellis, J., Perry, A.L., Low, P.J., Ellis, J.R., Reynolds, J.D., 2005. Climate change and distribution shifts in marine fishes. http://dx.doi.org/10.1126/ science. 1111322.

Somero, G.N., 2010. The physiology of climate change: how potentials for acclimatization and genetic adaptation will determine 'winners' and 'losers'. J. Exp. Biol. 213, 912-920.

Titselaar, F.F.L.M., 2019. Notes on the nomenclature of the macaronesian Patella candei d'Orbigbny complex, with special reference to Patella ordinaria Mabille and P. crenata Gmelin (Patellofastropoda, Patellidae). Basteria 83 (4-6) 158-165.

Tomanek, L., 2008. The importance of physiological limits in determining biogeographical range shifts due to global climate change: the heat-shock response. Physiol. Biochem. Zool. 81, 709-717.

Vélez-Belchí, P., González-Carballo, M., Pérez-Hernández, M.D., HernándezGuerra, A., 2015. Open ocean temperature and salinity trends in the Canary Current Large Marine Ecosystem. In: Valdés, L., Déniz-González, I. (Eds.) Oceanographic and Biological Features in the Canary Current Large Marine Ecosystem. In: IOC Technical Series, vol. 115, IOC-UNESCO, Paris, pp. 299-308, URI: http://hdl.h\{and\}le.net/1834/9196.

Wanninger, A., Ruthensteiner, S., Lobewein, W., Salvenmoser, W., Hasprunar, G., 1999. Development of the musculature in the limpet Patella (Mollusca, Patellogastropoda). Dev. Genes. Evol. 209, 226-238. http://dx.doi.org/10. 1007/s004270050247.

Wittmann, A.C., Pörtner, H., 2013. Sensitivities of extant animal taxa to ocean acidification. Nat. Clim. Chang. 3, 995-1001. http://dx.doi.org/10.1038/ nclimate 1982.

Yapici, S., Filiz, H., Bilge, G., 2016. Northwards range expansion of Sparisoma cretense (Linnaeus, 1758) in the turkish Aegean Sea. J. Aquac. Eng. Fish. Res. http://dx.doi.org/10.3153/JAEFR1602.

Zhang, H., Siu Gin, C., Paul, S., 2014. The larvae of congeneric gastropods showed differential responses to the combined effects of ocean acidification, temperature and salinity. Mar. Pollut. Bull. 79, http://dx.doi.org/10.1016/j. marpolbul.2014.01.008

Zhao, X.H., Jin, S.D., 2001. Influence of low temperature, salinity-lowering and ph on metamorphosis of chinese mitten-handed crab. J. Dalian Fish Coll 16 249-256.

Zhao, Q., Shin, P.K.S., Cheung, S.G., 2009. Effect of temperature and salinity on the larvae of two subtidal Nassariid gastropods, Nassarius siquijorensis and Nassarius crematus (Gastropoda, Nassariidae). Transylv. Rev. Syst. Ecol. Res 8 , 41-58. 